\title{
Seasonality of insects in the semi-arid Caatinga of northeastern Brazil
}

\author{
Alexandre Vasconcellos ${ }^{1,4}$, Ricardo Andreazze ${ }^{2}$, Adriana M. Almeida ${ }^{1}$, Helder F. P. Araujo ${ }^{3}$, \\ Eduardo S. Oliveira ${ }^{1} \&$ Uirandé Oliveira $^{1}$
}

\begin{abstract}
'Departamento de Botânica, Ecologia e Zoologia, Universidade Federal do Rio Grande do Norte, 59072-970 Natal-RN, Brazil. avasconcellos@cb.ufrn.br; adrianam@cb.ufrn.br; edutopiaeco@yahoo.com.br; dede_eco@hotmail.com

${ }^{2}$ Departamento de Microbiologia e Parasitologia, Universidade Federal do Rio Grande do Norte, 59072-970 Natal-RN, Brazil. andreazze@cb.ufrn.br ${ }^{3}$ Departamento de Ciências Biológicas, Universidade Federal da Paraíba, 58397-000 Areia-PB, Brazil. hfparaujo@yahoo.com.br

${ }^{4}$ Corresponding author
\end{abstract}

\begin{abstract}
Seasonality of insects in the semi-arid Caatinga of northeastern Brazil. Insects are essential to tropical ecosystems functioning. In semi-arid regions, the increase in abundance and/or activity (e.g. reproduction and foraging behavior) of insects is usually associated with climatic variables. The present study investigates which climatic variables are best predictors of insect abundance in an area of Caatinga in northeastern Brazil. Individuals were sampled for 24 months using Malaise and pitfall traps, and beating trays. A total of 58925 individuals belonging to 20 insect orders were collected. The most abundant orders were Hymenoptera, Diptera, Collembola and Coleoptera. Most orders studied showed a clear maximum abundance in the rainy season. Rainfall and humidity were the best predictors of insect abundance in the Caatinga. However, no climatic variable could explain Psocoptera and Blattodea variance in abundance/activity. Our results suggest that climatic changes associated with rainfall patterns in the Caatinga may affect ecosystem processes and services that depend direct or indirectly on insect abundance/activity.
\end{abstract}

KEYWORDS. Abundance; climatic variables; insect availability; Neotropical region.

RESUMO. Sazonalidade de insetos na Caatinga do Nordeste Brasileiro. Os insetos são abundantes e essenciais para o funcionamento dos ecossistemas terrestres tropicais. No entanto, a abundância e/ou atividade (e.g. reprodução ou forrageio) destes organismos podem ser fortemente influenciadas pelas variáveis climáticas. Este estudo examina quais as variáveis climáticas podem atuar como preditoras da abundância e/ou atividade dos insetos em uma área de Caatinga do Nordeste brasileiro. Ao longo de 24 meses, os insetos foram coletados mensalmente utilizando armadilhas Malaise, armadilhas tipo "pitfall" e guarda-chuva entomológico. Um total de 58925 indivíduos de 20 ordens foi coletado. As ordens mais abundantes foram Hymenoptera, Diptera, Collembola e Coleoptera. Entre as doze ordens mais abundantes, dez apresentaram os seus maiores picos durante a estação chuvosa. A precipitação e a umidade relativa foram os principais preditores dos padrões de abundância e/ou atividade dos insetos na caatinga. Nenhuma variável climática foi relacionada com o número de indivíduos coletados de Psocoptera e Blattodea. Os efeitos das variáveis climáticas sobre os insetos sugerem que alterações no clima da caatinga, especialmente em seu padrão de precipitação, podem afetar os serviços ecossistêmicos que dependem direta e indiretamente da abundância e/ou atividade destes organismos.

PALAVRAS-CHAVE. Abundância; disponibilidade de insetos; região Neotropical; variáveis climáticas.

Insects are abundant organisms in all terrestrial ecosystems, playing a key role, and affecting the primary and secondary production, energy flow and nutrient cycling. Insects can act as decomposers, herbivores, pollinators, seed dispersers, predators, parasites, ecosystem engineers as well as prey for a variety of vertebrates and other invertebrates. The exact role of insect species or their functional groups in terrestrial ecosystems will depend on populations numerical oscillations and intensity of foraging activity and reproduction. These activities will, in turn, be associated with seasonality and climatic conditions in ecosystems (Wolda 1988; Whitford 1996).

Seasonal climatic conditions can exert a strong influence on insect abundance and activity. In ecosystems with clear distinction between rainy and dry seasons, climatic variables are known to be good predictors of population behavior (Janzen 1973; Wolda 1988). However, insect responses to climate are not uniform and may vary according to habitat characteristics and the studied taxa (Janzen \& Schoener 1968; Levings \& Windsor 1985; Wolda \& Broadhead 1985). Some insect species may present a strong synchrony with climatic patterns, such as temperature and rainfall, while some species present various peaks in abundance throughout the year or may even show preferences for the dry season (Wolda 1980; Wolda \& Fisk 1981; Wolda 1988).

The Caatinga represents one of the largest seasonal savanna in the world, encompassing $c a .735 .000 \mathrm{~km}^{2}$ of the Brazilian Northeast Region (Andrade-Lima 1981; Prado 2003). Its physiognomy presents as a mosaic of different forest types, characterized by trees and shrubs with spines and various adaptations to water deficit (Prado 2003). Average rainfall in the Caatinga varies from $240 \mathrm{~mm}$ to $1500 \mathrm{~mm}$. Rainfall is less than $750 \mathrm{~mm}$ in about half of Caatinga geographical region. Between $50 \%$ to $70 \%$ of annual rainfall is concentrated in only three consecutive months, characterizing the area as a strong seasonal climate (Sampaio 1995; Prado 2003). The Caatinga has been severely altered by slash-and-burn agriculture, harvesting of firewood, hunting, and from the continuous action of cattle and goat herds, and today only a small portion is well-preserved and protected (Leal et al. 2005). 
The main objectives of the present study were to investigate and identify climatic variables that could be good predictors of insect abundance and/or activity (related to foraging and reproductive activity) in a Caatinga area in NE Brazil. The insect fauna of the Caatinga is poorly known and little is understood as about organism strategies in face of such a high water stress (Lewinsohn et al. 2005). Studies on the influence of climatic variables on insect communities in the Caatinga are rare and information is available for a few groups, such as Apoidea (Aguiar \& Martins 1997; Zanella \& Martins 2003), Sphingidae (Gusmão \& Creão-Duarte 2004), Buprestidae (Iannuzzi et al. 2006) and Scarabeidae (Hernández 2007).

\section{MATERIAL AND METHODS}

\section{Study site}

The study was performed at the Private Reserve for the Environmental Inheritance of Fazenda Almas (RPPN-Fazenda Almas) (07 28'S; $\left.36^{\circ} 52^{\prime} \mathrm{W}\right)$, situated between São José dos Cordeiros and Sumé (State of Paraíba), 300km from the coast. The study area encompasses an area of 3505 ha varying from $600 \mathrm{~m}$ to $720 \mathrm{~m}$ a.s.l. with an irregular topography and sandy soil, with inselbergs and rocky outcrops. Vegetation presents a strong deciduous characteristic, and almost all leaves are lost during dry season.

Monthly rainfall from 2006 to 2008 were obtained from "Agência Executiva de Gestão das Águas do Estado da Paraíba" (Governo da Paraíba 2008). Some data were obtained for the municipality of Sumé: real evapotranspiration, water deficit/excess (CPTEC 2008). Monthly temperature and relative humidity were obtained in each sample point with a digital thermohygrometer. Values were calculated from six days, with five daily values between 05:00 am and 12:00 am.

Even though the Caatinga presents a characteristic dry season, its length may vary (Sampaio 1995). Rainy and dry seasons were defined for the study area based on values of rainfall and water deficit/excess for the region (Fig. 1). With this methodology, the dry season was defined as the period between August and January, when the lowest and maximum water deficit were detected.

\section{Insect sampling}

Insects were sampled monthly for 24 months, from December 2006 to November 2008. Every sampling trip lasted six days. The sampling area was delimited within a 100ha grid near the center of the biggest forest remnant in the RPPN-Fazenda Almas. The sampling grid was composed of six $1 \mathrm{~km}$ parallel transects (A, B, C, D, E, F), distant $200 \mathrm{~m}$ from each other. Each transect presented six points distant $200 \mathrm{~m}$. At each month one point was sampled in each transect. Each point was sampled twice a year, with one sampling per season.

Insect sampling was conducted with Malaise traps (surface of $\left.2 \mathrm{~m}^{2}\right)$, pitfall traps $(15 \mathrm{~cm}$ mouth diameter and $10 \mathrm{~cm}$ high) and beating trays. Six Malaise traps were left in the field for one day every month. Five pitfall traps were placed in each point and were displaced in a cross-shaped design, with one in the center and four in each cross top, distant $1 \mathrm{~m}$ from each other. Pitfalls were connected by a plastic device $15 \mathrm{~cm}$ high, which amplified the sampling power. With this design, the pitfall traps increased sampling surface to $4 \mathrm{~m}^{2}$. At each point, four trees were sampled by beating trays and all collected insects were pooled into one sample. Samples were taken to Laboratório de Ecologia e Conservação da Biodiversidade (LECOB) and to Laboratório de Entomologia in Universidade Federal do Rio Grande do Norte, where individuals were classified according to order and counted. Monthly insect abundance per order, with pooled sampling methods was used in following analyses.

\section{Data analysis}

Forward stepwise multiple regressions were used to determine which climatic variables were significant predictors of abundance for each insect order. However, only data on the most abundant orders were analyzed. Variables were included into the model when the F-value was significant $(\mathrm{P} \leq 0.05)$ and removed when probability $F$-value was $P \geq 0.10$. Ten variables were selected as possible predictors: total monthly rainfall $(\mathrm{mm})$, average monthly temperature $\left({ }^{\circ} \mathrm{C}\right)$, average monthly relative humidity $(\%)$, average actual evapotranspiration $(\mathrm{mm})$, and water excess/deficit (mm). The same procedures were repeated with variables detected from one preceding month. This analysis was conducted in order to test for timelag responses in abundance or activity from the studied insect orders to the climatic variables in the preceding month.

\section{RESULTS}

A total of 58925 insect individuals belonging to 20 orders were obtained in 24 months. The most abundant orders were Hymenoptera (35.0\%), Diptera (29.2\%), Collembola (21.4\%), Coleoptera $(4.1 \%)$, Homoptera $(2.8 \%)$, Orthoptera $(2.1 \%)$, Lepidoptera $(1.3 \%)$, Isoptera $(1.2 \%)$, Hemiptera $(0.7 \%)$, Thysanura $(0.3 \%)$, Psocoptera $(0.3 \%)$ and Blattodea $(0.2 \%)$. The orders Dermaptera, Embioptera, Mallophaga, Mantodea, Neuroptera, Phasmida, Siphonoptera and Thysanoptera encompassed less than $0.5 \%$ of obtained individuals. The pitfall and Malaise traps were the most efficient capture methods, with $67 \%$ and $28 \%$ of all sampled individuals, respectively.

Ten in the twelve most abundant orders presented higher abundance during the rainy season, with Blattodea and Psocoptera being the exceptions (Fig. 2). The orders Isoptera, Coleoptera, Diptera, Homoptera and Orthoptera showed the best-defined abundance peaks within the rainy season. Eight orders showed high peaks in the rainy season in 2008, when rainfall values were higher than the previous year. Collembola showed only one peak in the beginning of 2008 rainy season.

Rainfall (with no time lag or with one-month lag) was the climatic variable that best explained insect abundance/ activity in the Caatinga (Table I) as shown by stepwise regression. Relative humidity was the second climatic variable that exerted influence on insect populations, relating to four orders. 


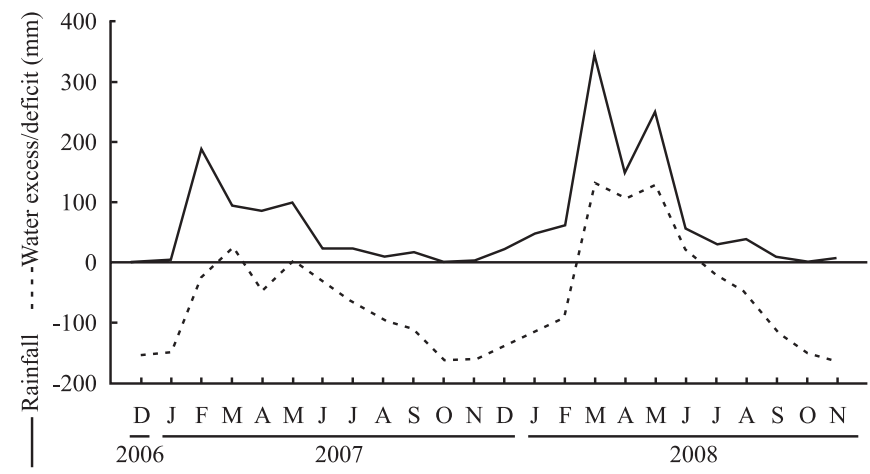

Fig. 1. Monthly rainfall variation and water excess/deficit for the municipality of Sumé, from December 2006 to November 2008.

\section{DISCUSSION}

Abundance patterns were mainly explained by rainfall and humidity. Rainfall seasonality patterns present a stronger influence on insect abundance in tropical terrestrial ecosystems than temperature ones, which in turn seem to be more important in the subtropics and the temperate zone (Wolda 1988; Basset 1991). Both rainfall and substrate humidity exert a strong influence on insect assemblages in various Neotropical ecosystems (Davies 1945; Janzen 1973; Wolda 1978; Levings \& Windsor 1984; Develey \& Peres 2000; Hernández 2007). On the other hand, the seasonal pattern of insect abundance in the Cerrado (seasonal savannah-like biome in Brazil), was little affected by climatic variables, with the exception of Coleoptera that responded to maximum temperature and humidity (Pinheiro et al. 2002).

Both Psocoptera and Blatodea showed no direct response to the investigated variables. This suggests that other abiotic or biotic factors (e.g. competition) not considered here could be working in the Caatinga. In Barro Colorado Island, Panama, Psocoptera abundance also showed little seasonal tendencies, but different species showed clear individual patterns throughout the year, even within the same season. This suggests a temporal niche differentiation due to interspecific competition (Wolda \& Broadhead 1985). Similarly to what was described to Psocoptera, Blattodea did not show a seasonal pattern in three climatically different localities in Panama, even though there was some tendency for adults of some species to spread out over the season (Wolda \& Fisk 1981).

The beginning of the rainy season may be followed by a rapid response in insect abundance, such as Isoptera, which present a great amount of alate individuals. Some Homoptera and Lepidoptera species may also show a similar behavior, since some species are able to emerge from nymphs and pupae from soil profile. Termites reproductive flights show a strong seasonal pattern in the tropics, responding primarily to temperature and rainfall (Nutting 1969). According to Wolda (1978), alteration in soil humidity and changes in root plant activities can influence adult cicada emergence. This group shows a strong relation to rainfall patterns in the lowland tropical monsoon forest in Barro Colorado Island. In other Caatinga area, the soil humidity was considered an important predictor of adult moth abundance captured in light traps (Gusmão \& Creão-Duarte 2004).

A relatively rapid response in insect abundance at the beginning of the rainy season in Caatinga may be the result of the movement of individuals from humid vegetation patches around water reservoirs and perennial rivers and also from highland rainforest that are included in Brazilian Caatinga. The greater amount of food and milder climate in habitats with a severe dry season may attract insects from adjacent habitats that are not so strongly influenced by seasonality (Janzen \& Schoener 1968). In the Caatinga dominium there are some highland areas that support rainforests. These places may act as a refuge in the dry season for insects with a good dispersal ability or source area when the rainy season is beginning in the Caatinga, as already shown for some vertebrate species (Vanzolini 1981; Sousa 2004). There are few studies comparing insect communities from highland rainforests and adjacent Caatinga areas, but many Euglossini and Scarabeidae species were found in both (Locatelli et al. 2004; Silva et al. 2007). Gusmão \& Creão-Duarte (2004)

Table I. Stepwise regression parameters for the 12 most abundant orders of insects and the environmental variables: total monthly rainfall (mm), monthly average temperature-Temp $\left({ }^{\circ} \mathrm{C}\right)$, monthly average relative humidity-RH $(\%)$ and monthly average actual evapotranspiration-ETP (mm), and water excess/ deficit-WED (mm). These variables were also used with one preceding month (-1).

\begin{tabular}{|c|c|c|c|c|c|c|c|c|c|c|c|c|}
\hline \multirow[t]{2}{*}{ Order } & \multicolumn{12}{|c|}{ Climatic variables } \\
\hline & $\mathrm{R}_{\text {adj }}^{2}$ & F-value & Rainfall & Rainfall (-1) & Temp & Temp (-1) & $\mathrm{RH}$ & $\mathrm{RH}(-1)$ & ETP & $\operatorname{ETP}(-1)$ & WED & WED (-1) \\
\hline Blattodea & 0.004 & 1.10 & & & & & & & & & & \\
\hline Collembola & 0.44 & $6.78^{* *}$ & $3.43 * *$ & & & & & & & & & \\
\hline Coleoptera & 0.73 & $11,16^{* *}$ & $3.40 * *$ & $2.76^{*}$ & & & $-2.37 *$ & & & & & \\
\hline Diptera & 0.67 & $9.81 * *$ & $3,02 * *$ & & & $2.16^{*}$ & & & & & $2.36^{*}$ & \\
\hline Hemiptera & 0.79 & $12.71 * *$ & $2.58^{*}$ & $4.61 * *$ & & & $3.67 * *$ & & & & & \\
\hline Homoptera & 0.65 & $14.80^{* *}$ & & & & & & & $2.90 * *$ & & & $2.56^{*}$ \\
\hline Hymenoptera & 0.39 & $4.59 * *$ & & & & & $-2.24 *$ & & & $3.97 * *$ & & \\
\hline Isoptera & 0.28 & $9.59 * *$ & & $3.09 * *$ & & & & & & & & \\
\hline Lepidoptera & 0.17 & $3.15^{*}$ & & & & & & & & $2.24^{*}$ & & \\
\hline Orthoptera & 0.80 & $15.36^{* *}$ & & $4.29 * *$ & & & & & & & & $-2.51^{*}$ \\
\hline Psocoptera & 0.05 & 2.07 & & & & & & & & & & \\
\hline Thysanura & 0.68 & $7.5 * *$ & & $2.70 *$ & -2.71 & & $-3.29 * *$ & & & & & \\
\hline
\end{tabular}




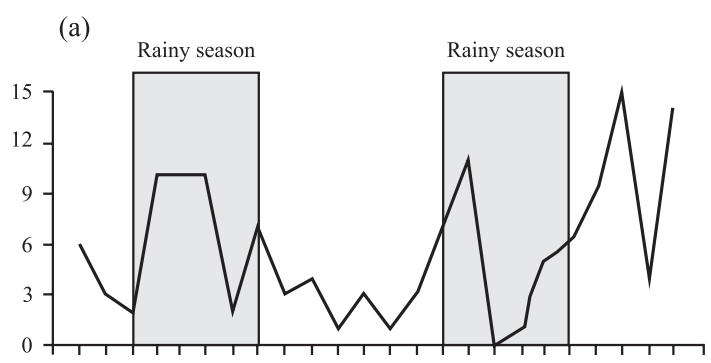

(c)

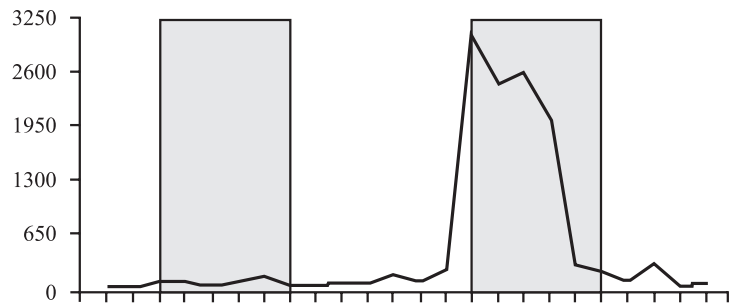

(e)

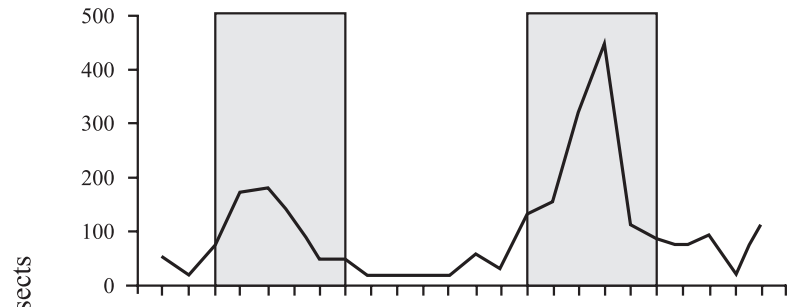

(g)

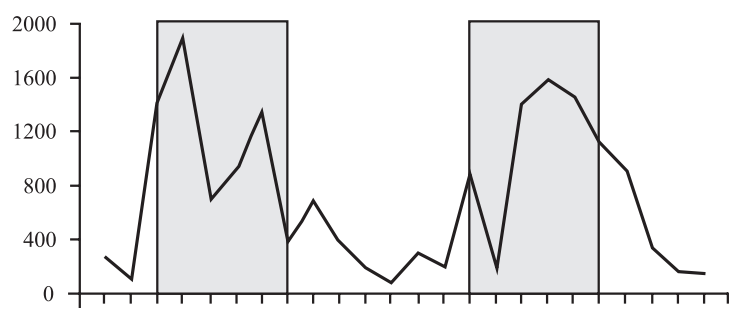

(i)

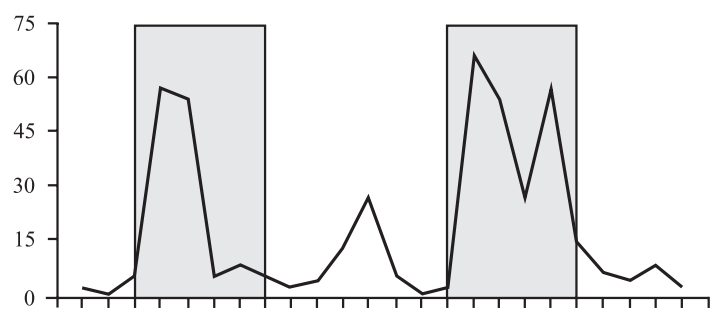

(1)

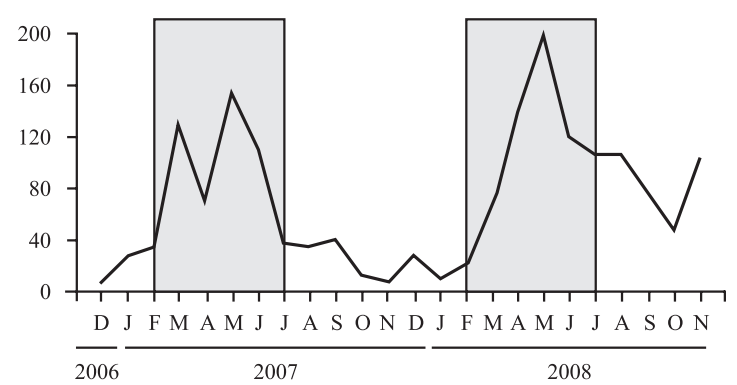

(b)

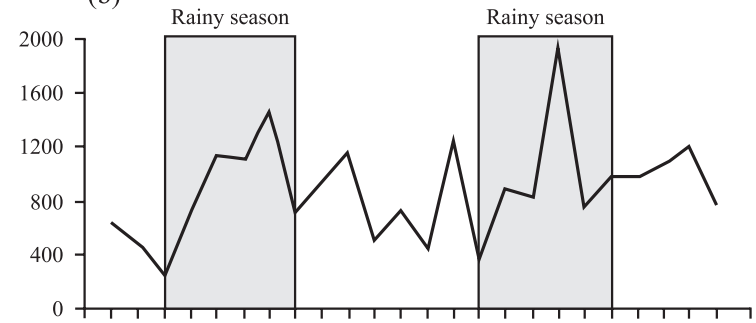

(d)

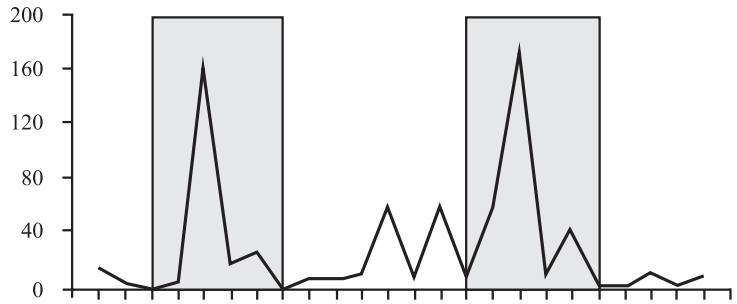

(f)

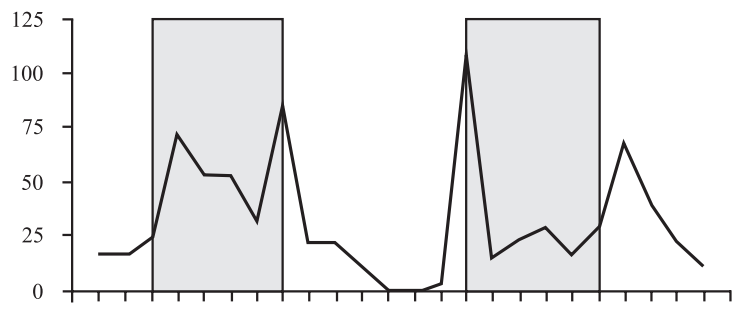

(h)

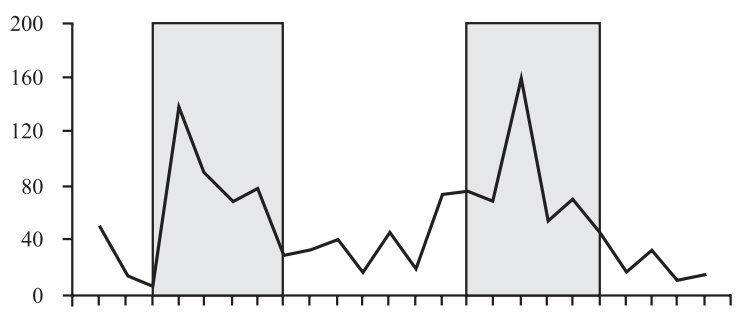

(j)

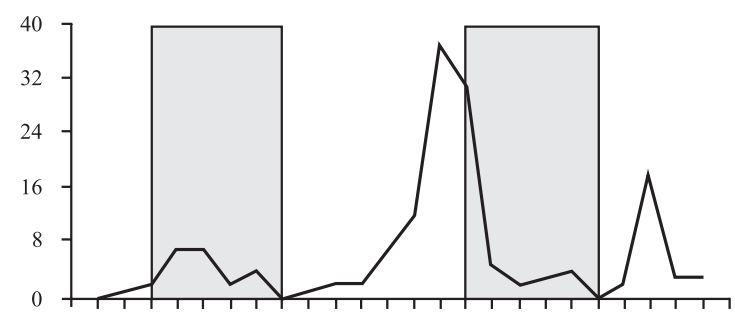

(m)

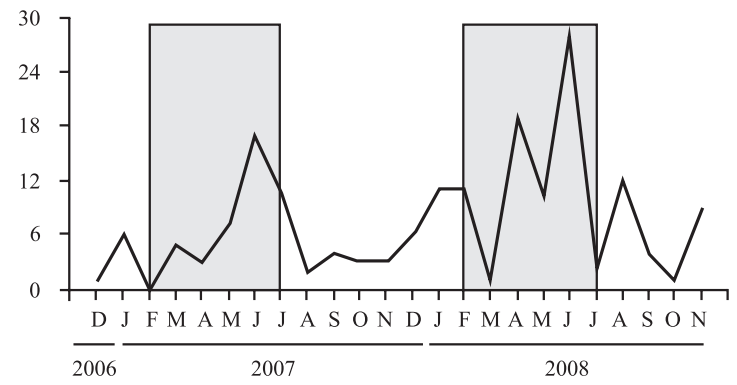

Fig. 2. Abundance of the 12 most abundant orders of insects collected between December 2006 and November 2008 in an area of Caatinga, Northeast Brazil. (a) Blattodea, (b) Hymenoptera, (c) Collembola, (d) Isoptera, (e) Coleoptera, (f) Lepidoptera, (g) Diptera, (h) Orthoptera, (i) Hemiptera, (j) Psocoptera, (l) Homoptera, $(\mathrm{m})$ Thysanura. Shaded bars indicate the rainy season. 
detected more than $50 \%$ similarity in Sphingidae species composition between a highland rainforest fragment and an adjacent Caatinga.

Another factor that may be contributing to the higher insect abundance in the Caatinga may be related to the influence of humidity on the activity of organisms. This will direct or indirectly include litter decomposition stored during the dry season. Soil humidity is a determinant factor in increasing biomass of soil microorganisms, stimulating saprophagous and predator arthropod species that are part of the soil micro-, meso- and macrofauna (Swift et al. 1979; Lavelle et al. 1995). On the other hand, decomposition is also reduced at high levels of soil moisture (Haynes 1986). In another study conducted in RPPN-Fazenda Almas, Moura et al. (2006a, b) detected that foraging and food ingestion in the termite Constrictotermes cyphergaster was significantly higher in the rainy season. According to Whitford (1996), guilds and species of soil organisms that are active at a particular time in arid and semi-arid ecosystems are determined by abiotic factors, mainly rainfall.

The predictable rainy season in the Caatinga promotes a significant increase in plant biomass, and most species produce flowers and fruits at this season (Machado et al. 1995). Aguiar \& Martins (1997) found that the strong decrease in number of bees in the dry season was mainly due to the lack of floral resources in this season. The increase in plant biomass during the rainy season represents an increase in resources for many Diptera, Orthoptera, Homoptera, Lepidoptera (both larvae and adults), Hymenoptera and Coleoptera species. On the other hand, a few plant species are able to produce flowers and leaves in the dry season (Machado et al. 1995). That could be an important source for insect populations during the dry season. Besides, the increase in plant biomass for vertebrate herbivores, including cattle, also brings resources in the form of feces, mainly for beetles and flies in the Caatinga. Hernández (2007) detected a strong seasonal pattern in Scarabeidae abundance in the Caatinga, with no adult species observed during the dry season.

The increase in insect abundance certainly affects the population of other predator and parasitoid insects, as observed for Mantodea and some Hymenoptera species in Panama forests (Fogden 1972; Wolda 1978). The increase in prey numbers will also affect vertebrates, such as birds, amphibians and reptiles. In the Caatinga, the Arthropod abundance seems to influence the geographical distribution, reproductive period and flock composition of birds (HFP Araujo unpublished data). Similar observations had been reported for arid and semi-arid areas of the northeastern Venezuela, where the reproductive activity of birds is associated with the rainy season. During this period the abundance of arthropods is greater (Poulin et al. 1992). Considering the abundance in consumption, insects correspond to the main food resource consumed by birds in both the Caatinga and the arid and semi-arid areas of Venezuela (Poulin et al. 1994; HFP Araujo unpublished data).

Climatic changes exert a strong influence in agriculture and water availability, mainly in semi-arid regions. In Latin
America, projections indicate a slight increase in temperature and higher variability in rainfall patterns for the next decades (Silva 2004; Sivakumar et al. 2005). In the Caatinga both dramatic rainfall decreases and significant increases should be considered plausible on the time scale of 50 years (Krol $\&$ Bronstert 2007). The effects of climatic variables on insect abundance/activity suggest that Caatinga climatic changes, mainly in rainfall patterns, may affect ecosystem services that are direct or indirectly associated to these organisms.

Acknowledgments. The authors are grateful to Mrs. Eunice Braz, owner of the RPPN-Fazenda Almas, for the logistic support during this research, and Dr. Elvio S. F. Medeiros and Flávia M. S. Moura, for valuable comments. Financial support was provided by the Brazilian Long Term Ecological Research Project (PELD-Caatinga/CNPq).

\section{REFERENCES}

Aguiar, C. M. L. \& C. F. Martins. 1997. Abundância relativa, diversidade e fenologia de abelhas (Hymenoptera, Apoidea) na Caatinga, São João do Cariri, Paraíba, Brasil. Iheringia série Zoologia 83: 151-163.

Andrade-Lima, D. 1981. The caatinga dominium. Revista Brasileira de Botânica 4: 149-163.

Basset, Y. 1991. The seasonality of arboreal arthropods foraging within an Australian rainforest tree. Ecological Entomology 16: 265-278.

CPTEC - Centro de Previsão de Tempo e Estudos Climáticos. 2008. Programa de Monitoramento Climático em Tempo Real da Região Nordeste (Available from: http://www.cptec.inpe.br/proclima) (accessed 15 December 2008).

Davies, D. E. 1945. The annual cycle of plants, mosquitoes, birds and mammals in two Brazilian forests. Ecological Monographs 15: 243-295.

Develey, P. F. \& C. A. Peres. 2000. Resource seasonality and the structure of mixed species bird flocks in a coastal Atlantic forest of southeastern Brazil. Journal of Tropical Ecology 16: 33-53.

Fogden, M. P. L. 1972. The seasonality and population dynamics of equatorial Forest birds in Sarawak. Ibis 114: 307-343.

Governo da Paraíba. 2008. Agência Executiva de Gestão das Águas do Estado da Paraíba (Available from: http://www2.aesa.pb.gov.br/meteoro/ pcdlmrs.shtml) (accessed 15 December 2008).

Gusmão, M. A. B. \& A. J. Creão-Duarte. 2004. Diversidade e análise faunística de Sphingidae (Lepidoptera) em área de brejo e caatinga no Estado da Paraíba, Brasil. Revista Brasileria de Zoologia 21: 491-498.

Haynes, R. J. 1986. The decomposition process: mineralization, immobilization, humus formation, and degradation, p. 52-126. In: R. J. Haynes (ed.). Mineral nitrogen in the plant-soil system. Orlando, Academic press, $287 \mathrm{p}$.

Hernández, M.I. M. 2007. Besouros escarabeineos(Coleoptera: Scarabaeidae) da caatinga paraibana, Brasil. Oecologia Brasiliensis 11: 356-364.

Iannuzzi, L.; A. C. D. Maia \& S. D. Vasconcelos. 2006. Ocorrência e sazonalidade de coleópteros buprestídeos em uma região de caatinga nordestina. Biociências 14: 174-179.

Janzen, D. H. \& T. W. Schoener. 1968. Differences in insect abundance and diversity between wetter and drier sites during a tropical dry season. Ecology 49: 96-110.

Janzen, D. H. 1973. Sweep samples of tropical foliage insects: effects of seasons, vegetation types, elevation, time of day, and insularity. Ecology 54: $667-701$.

Krol, M. S. \& A. Bronstert. 2007. Regional integrated modelling of climate change impacts on natural resources and resource usage in semiarid Northeast Brazil. Environmental Modelling \& Software 22: 259-268.

Lavelle, P.; D. T. Lattaud \& I. Barois. 1995. Mutualism and biodiversity in soils. Plant Soil 170: 23-33.

Leal, I. R.; J. M. C. Silva; M. Tabarelli \& T. E. Lacher. 2005. Changing the course of biodiversity conservation in the Caatinga of northeastern Brazil. Conservation Biology 19: 701-706. 
Levings, S. C. \& D. M. Windsor. 1984. Litter moisture content as a determinant of litter Arthropod distribuition and abundance during the dry season on Barro Colorado Island, Panama. Biotropica 16: 125-131.

Levings, S. C. \& D. M. Windsor. 1985. Litter Arthropod populations in a tropical deciduous forest: relations between years and Arthropod groups. Journal Animal Ecology 54: 61-69.

Lewinsohn, T. M.; A. V. L. Freitas \& P. I. Prado. 2005. Conservation of terrestrial invertebrates and their habitats in Brazil. Conservation Biology 19: 640-645.

Locatelli, E.; I. Machado \& P. Medeiros. 2004. Diversidade de abelhas e a flora apícola em um fragmento de Mata Serrana (Brejos de Altitude) em Pernambuco, Nordeste do Brasil, p. 153-177. In: K. Pôrto; M. Tabarelli \& I. C. Machado (eds.). Brejos de Altitude: História Natural, Ecologia e Conservação. Brasília, MMA/PROBIO/CNPq, 324 p.

Machado, I. C. S.; L. M. Barros \& E. V. S. B. Sampaio. 1995. Phenology of Caatinga Species at Serra Talhada, PE, Northeastern Brazil. Biotropica 29: $57-68$.

Moura, F. M. S.; A. Vasconcellos; V. F. P. Araújo \& A. G. Bandeira. 2006 a. Seasonality in foraging behaviour of Constrictotermes cyphergaster (Termitidae, Nasutitermitinae) in the Caatinga of northeastern Brazil. Insectes Sociaux 53: $1-8$.

Moura, F. M. S., A. Vasconcellos; V. F. P. Araujo \& A. G. Bandeira. $2006 \mathrm{~b}$. Feeding habit of Constrictotermes cyphergaster (Isoptera, Termitidae) in an area of caatinga, Northeast Brazil. Sociobiology 48: 21-26.

Nutting, W. L. 1969. Flight and colony foundation, p. 233-282. In: K. Krishna \& F. M. Weesner (eds). Biology of termites. vol I., New York, Academic Press, 598 p.

Pinheiro, F.; I. R. Diniz; D. Coelho \& M. P. S. Bandeira. 2002. Seasonal pattern of insect abundance in the Brazilian cerrado. Austral Ecology 27: 132-136.

Poulin, B.; G. Lefebvre \& L. R. Mcneil. 1992. Tropical avian phenology in relation to abundance and exploitation of food resources. Ecology 73: 2295-2309.

Poulin, B; G. Lefebvre \& L. R. Mcneil. 1994. Diets of land birds from northeastern Venezuela. The Condor 96: 354-367.

Prado, D. 2003. As caatingas da América do Sul, p. 3-73. In: I. R. Leal \& M. Tabarelli \& J. M. C. Silva (eds). Ecologia e conservação da Caatinga. Recife, Universidade Federal de Pernambuco, 804 p.
Sampaio, E. V. S. B. 1995. Overview of the Brazilian Caatinga, p. 35-58. In: S. H. Bullock, H. A. Mooney \& E. Medina (eds.). Seasonally dry forests. Cambridge, Cambridge University Press, Cambridge, 875 p.

Silva, V. P. R. 2004. On climate variability in Northeast of Brazil. Journal Arid Environments 58: 575-596.

Silva, F. A. B; M. I. M. Hernández; S. Ide \& R. C. Moura. 2007. Comunidade de escarabeíneos (Coleoptera, Scarabaeidae) copro-necrófagos da região de Brejo Novo, Caruaru, Pernambuco, Brasil. Revista Brasileria de Entomologia 51: 228-233.

Sivakumar, M. V. K.; H. P. Das \& O. Brunini. 2005. Impacts of Present and Future Climate Variability and Change on Agriculture and Forestry in the Arid and Semi-Arid Tropics. Climate Change 70: 31-72.

Sousa, M. A. N.; A. Langguth \& E. A. Gimenez. 2004. Mamíferos dos Brejos de Altitude de Paraíba e Pernambuco, p. 229-254. In: K. Pôrto; M. Tabarelli \& I. C. Machado (eds). Brejos de Altitude: História Natural, Ecologia e Conservação. Brasília, MMA/PROBIO/CNPq, 324 p.

Swift, M. J.; O. W. Heal \& J. M. Anderson. 1979. Decomposition in terrestrial ecosystems. London, Blackwell Scientific Publications, $372 \mathrm{p}$.

Vanzolini, P. E. 1981. A quasi-historical approach to the natural history of the differentiation repteis in tropical geographic isolates. Papéis Avulsos de Zoologia 34: 189-204.

Whitford, W. G. 1996. The importance of the biodiversity of soil biota in arid ecosystems. Biodiversity and Conservation 5: 185-195.

Wolda, H. 1978. Seasonal fluctuations in rainfall, food and abundance of tropical insects. Journal Animal Ecology 47: 369-381.

Wolda, H. 1980. Seasonality of tropical insects: I Leafhoppers (Homoptera) in Las Cumbres, Panama. Journal of Animal Ecology 49: 277-290.

Wolda, H. 1988. Insect seasonality:Why? Annual Review of Ecology and Systematics 19: 1-18.

Wolda, H. \& E. Broadhead. 1985. Seasonality of Psocoptera in two tropical forests in Panama. Journal of Animal Ecology 54: 519-530.

Wolda, H. \& F. W. Fisk. 1981. Seasonality of tropical insects. II Blataria in Panama. Journal of Animal Ecology 50: 827-838.

Zanella, F. C. V. \& C. F. Martins. 2003. Abelhas da Caatinga: Biogeografia, Ecologia e Conservação, p. 75-134. In: I. R. Leal; M. Tabarelli \& J. M. C. Silva (eds). Ecologia e conservação da Caatinga. Recife, Universidade Federal de Pernambuco, 804 p. 